\title{
Change of Sprouting-related Enzymes Activities and Food Quality Characteristics of Sweetpotato Root (Ipomea batatas Lam.) by Electron Beam Irradiation
}

\author{
Sung Jin Lim • Mi Seon Song • Gyeong Ae Lee · Jae-Young Cho*
}

\section{전자빔 조사에 의한 고구마의 발아관련 효소의 활성과 식품특성 변화}

임성진 · 송미선 · 이경애 · 조재영*

Received: 10 August 2012 / Accepted: 20 September 2012 / Published Online: 31 December 2012

(C) The Korean Society for Applied Biological Chemistry 2012

\begin{abstract}
We investigated that electron beam irradiation is the effective method to control the sprouting of sweetpotato roots without changing of food quality characteristics. In 12 and $25^{\circ} \mathrm{C}$ storage after electron beam irradiation, all control samples were sprouted from 6 and 4 weeks after storage, respectively. The sprouting rate of control increased with time and the rate reached to $11.2-12.4$ and $70.5-74.2 \%$ at 8 weeks after 12 and $25^{\circ} \mathrm{C}$ storage. Also, the sprouting of middle and below positioning sweetpotato roots at 12 and $25^{\circ} \mathrm{C}$ storage after irradiation reached to $8.6-11.3$ and $42.7-48.7 \%$ after a storage period of 8 weeks, respectively. However, the sprouting of all sweetpotato roots stored at $4^{\circ} \mathrm{C}$ and upper $(0-7 \mathrm{~cm})$ positioning samples of box stored at 12 and $25^{\circ} \mathrm{C}$ with electron beam was completely inhibited due to increase peroxidase and indole acetic acid (IAA) oxidase activity. Also, all samples with electron beam such as hardness, $\mathrm{pH}$, sugar content, weight loss, and vitamin $\mathrm{C}$ and dacarotene content did not differ from that of the control. Therefore, if electron beam will be irradiated to sweetpotato roots above $0.1 \mathrm{kGy}$ before packing, it will effectively inhibit their sprouting stored at $25^{\circ} \mathrm{C}$ without the change of food quality characteristics.
\end{abstract}

Keywords $\alpha$-amylase $\cdot$ electron beam $\cdot$ indole acetic acid oxidase $\cdot$ peroxidase $\cdot$ sprouting inhibition $\cdot$ sweetpotato root

S. J. Lim and M. S. Song contributed equally.

S. J. Lim $\cdot$ M. S. Song $\cdot$ G. A. Lee $\cdot$ J.-Y. Cho

Department of Bio-Environmental Chemistry, Chonbuk National University, Jeonju 561-756, Republic of Korea

*Corresponding author (J.-Y. Cho: soilcosmos@jbnu.ac.kr)
서 론

고구마(Ipomea batatas L.)는 항산화, 항세균 및 항암활성과 심 장질병, 백내장 및 스트레스 예방 효과를 가지는 vitamin, anthocyanin 및 $\beta$-carotene(Kirnski, 1993; Ameny와 Wilson, 1997; Suda 등, 1999) 등의 기능성물질을 다량 함유하고 있다(Reddy 와 Sistrunk, 1980; Shi 등, 1992). 최근 고구마는 기능성 식품 으로서의 소비 급증으로 인해 유럽과 서남아시아로의 수출이 증 가(AFMC, 2010)하고 있고, 미국을 포함한 미 수출국가에 대해 서도 수출이 시도되고 있다. 수-출입 과정에서의 고구마 품질 저하와 발아는 식물검역과정에 있어서 주된 문제로 지적되고 있 다. 더욱이 미국의 식물검역법은 수입 고구마의 자국 내 번식 제한을 위해 발아억제 처리를 요구하고 있다.

식물생장 조절제인 chloropropham과 maleic hydrazide는 감 자(Solanum rootosum L.), 마늘(Allium sativum L.) 및 양파 (Allium cepa L.)의 발아억제를 위해 광범위하게 사용되고 있지 만 잔류문제로 인해 고구마에 대해서는 사용이 허용되어 있지 않다(Lim 등, 2011). 반면, 전자빔은 저비용 - 고효율의 특성으 로 인해 감자, 보리(Hordeum vulgare L.) 및 밀(Triticum aestivum L.)의 발아 억제를 위해 사용하고 있다(Zacev 등, 1975; Sitton 등, 1995; Kottapalli 등, 2006).

식품조사는 식품 또는 식품 재료를 본래의 상태에 가깝게 보 존하거나 위생적 품질을 개선할 목적으로 방사선 에너지를 피 조사체에 노출시켜 생장조절, 해충제어, 미생물제어 등의 효과 를 거두는 기술로 일반적으로 파장이 짧은 감마선과 전자빔이 이용되고 있다. ${ }^{60} \mathrm{Co}$ 등 방사선 동위원소에 의해 발생되는 감마 선은 에너지의 투과력이 커서 포장된 식품 등 적용이 광범위하 다. 하지만 방사성 동위원소를 이용한다는 점에서 소비자들은 미지의 두려움을 느끼고 있어 감마선의 대안으로 전자빔이 주 목받고 있다. 전자가속기에 의해 생성되는 전자빔은 모든 생물 
계의 구성성분인 물과 반응하여 hydrated electron $\left(\mathrm{e}^{-}{ }_{\mathrm{aq}}\right)$, hydroxyl radical $\left(\mathrm{OH}^{*}\right)$, hydrogen radical $\left(\mathrm{H}^{*}\right)$, dihydrogen radical $\left(\mathrm{H}_{2} *\right)$, hydrogen peroxide radical $\left(\mathrm{H}_{2} \mathrm{O}_{2} *\right)$, hydrated hydroxide anion radical $\left(\mathrm{OH}_{\mathrm{aq}}^{-}\right)$, dihydrogen oxide radical $\left(\mathrm{H}_{2} \mathrm{O}^{*}\right)$ 및 superoxide anion radical $\left(\mathrm{O}_{2}^{-*}\right)$ 과 같은 radical을 생성(Chung 등, 2009)을 유도하고, 이로 인해 생성된 radical은 생물계에서 중요한 역할을 하는 효소를 활성화 또는 불활성화 하는 것으로 알려져 있다(Kagan 등, 1984; Saha 등, 1995; Latorre 등, 2010).

이에, 본 연구에서는 Korea Food and Drug Administration (KFDA, 2009), Ministry of Health, Labor and Welfare (MHLW, 2006), European Food Safety Authority (EFSA, 2011), Food and Drug Administration (FDA, 1986) 및 United States Department of Agriculture (USDA, 2011)의 과일과 채 소의 발아억제와 성숙지연에 허용되는 $1.0 \mathrm{kGy}$ 이하의 선량으 로 전자빔을 고구마에 조사한 후 발아와 밀접하게 관련되어 있는 $\alpha$-amylase(식물 성장에 필요한 에너지원 공급), peroxidase(옥신 분해) 및 indole acetic acid (IAA) oxidase(옥신 불활성화)의 활성변화와 고구마의 경도, $\mathrm{pH}$, 당도, 중량감소 및 $\beta$-carotene과 vitamin $\mathrm{C}$ 함량변화 등을 평가하여 고구마의 발아억제를 위한 물리적 처리방법으로서 전자빔의 적용가능성을 평가하였다.

\section{재료 및 방법}

실험재료. 본 연구에 사용된 고구마는 화산농협(해남)으로부터 구입하여 유사한 크기 $(10-13 \mathrm{~cm})$ 와 무게 $(70-80 \mathrm{~g})$ 를 가지는 것 으로 100 개를 선발하여 수출용 박스 $(40 \times 30 \times 17 \mathrm{~cm})$ 에 포장한 후 전자빔을 조사하였다.

전자빔 조사. 전자빔 조사는 $\mathrm{EB}-\mathrm{Tech}$ 사(Korea)의 electron beam accelerator (Model ELV-4)를 이용하여 $1 \mathrm{MeV}$ 의 beam energy로 가속전류 $40 \mathrm{~kW}$, beam dimension $75 \mathrm{~mm}$ (length) $\times 980 \mathrm{~mm}$ (width), velocity $20 \mathrm{~m} \mathrm{~min}^{-1}$ 의 선량률로 총 흡수선 량이 $0.1,0.2,0.5$ 및 $1.0 \mathrm{kGy}$ 로 3 반복 조사하였다. 전자빔 조 사 후 고구마는 전자빔 조사 시 박스의 위로부터 아래로 상층 $(0-7 \mathrm{~cm})$, 중간층 $(7-12 \mathrm{~cm})$ 및 하층 $(12-17 \mathrm{~cm})$ 에 위치했던 것으 로 다시 분류하여 박스에 넣은 다음 4 와 $12^{\circ} \mathrm{C}$ 저온저장고와 $25^{\circ} \mathrm{C}$ 의 실온에 8 주 동안 저장하며 실험재료로 사용하였다.

발아율. 상기의 방법으로 고구마에 전자빔을 조사한 후 박스의 각 층별로 고구마 100 개를 4,12 및 $25^{\circ} \mathrm{C}$ 에 저장하며 8 주에 걸쳐 고구마의 발아정도를 조사하여 백분율 $(\%)$ 로 나타내었다. 고구마의 식품특성 변화. 고구마의 식품특성에 끼치는 전자빔의 효과를 평가하고자 경도, $\mathrm{pH}$, 당도, 중량감소 및 $\beta$-carotene빔과 vitamin C 함량을 조사하였다. 고구마의 경도는 경도계(TAXT2i, SMS Co. Ltd., UK)를 이용하여 측정하였다. Plunger는 maximum force $5 \mathrm{~kg}$ 인 직경 $3 \mathrm{~mm}$ 의 것을 사용하여 $1.0 \mathrm{~mm}$ $\mathrm{s}^{-1}$ 의 관통속도로 측정하였다(Yun 등, 2008). $\mathrm{pH}$ 측정은 고구마 $(100 \mathrm{~g})$ 을 믹서기로 분쇄한 후 여과(Whatman No. 2)하여 얻은 여액에 증류수를 첨가 $(1: 5, \mathrm{v} / \mathrm{v})$ 하고 $\mathrm{pH}$ meter (Mettler Toledo, USA)를 이용하여 측정하였고(Yun 등, 2008), 당도는 고구마(10 $\mathrm{g})$ 에 $50 \mathrm{~mL}$ 증류수를 넣고 믹서기로 분쇄한 후 여액을 디지털 굴절계(PR-101a, CORETECH Co, Korea)로 측정하였다(Kirca 등, 2007). 중량변화는 각 시험구별로 고구마 10 개를 플라스틱 상자에 넣은 다음 2 주 간격으로 무게를 측정하여 그 변화율을
백분율 $(\%)$ 로 나타내었다(Yun 등, 2008). 비타민 C 함량은 믹서 기를 사용하여 분쇄한 고구마 $(2.5 \mathrm{~g})$ 에 $5 \%$ methaphosphoric acid $50 \mathrm{~mL}$ 를 넣고 초음파 추출 후 여과(Whatman No. 2) 한 다음 $530 \mathrm{~nm}$ 에서 분광광도계법(Optizen 2120AU, Mecasys, Korea)으로 측정하였다(KFDA, 2004). $\beta$-Carotene 함량은 고구 마 $5 \mathrm{~g}$ 을 농축플라스크에 칭량한 후 ethanol $30 \mathrm{~mL}, 10 \%$ pyrogallol/ethanol $1 \mathrm{~mL}, \mathrm{KOH} 3 \mathrm{~mL}$ 를 가해 혼합 후 $90^{\circ} \mathrm{C}$ 에서 30 분간 환류냉각 하였다. 증류수 $50 \mathrm{~mL}$ 를 이용해 분액여두로 추출액을 옮기고, petroleum ether $(25 \mathrm{~mL} \times 2$ 회 $)$ 로 추출하여 감 압건고 하고, 건고물을 isopropanol:chloroform (v/v, 1:1)으로 용 해한 후 HPLC (HPLC, D-2000 Elite, Hitachi, Japan)로 분석 하였다. 기기의 분석조건은 column : aquasil $\mathrm{C}_{18}$ column $(4.6 \mathrm{~mm}$ $\times 250 \mathrm{~mm}, 5 \mu \mathrm{m})$, mobile phase : acetonitrile: dichloromethane : methanol $(7: 3: 1, \mathrm{v} / \mathrm{v} / \mathrm{v})$, wavelength: $450 \mathrm{~nm}$, flow rate: $1.0 \mathrm{~mL}$ $\mathrm{min}^{-1}$, injection volume: $20 \mu \mathrm{L}$ 이었다(Dias 등, 2010). 상기의 모든 시험결과는 3 회 반복 측정하여 평균값으로 나타냈다.

발아관련 효소의 활성변화. $\alpha$-Amylase, peroxidase 및 IAA oxidase 활성분석을 위한 효소 조추출물은 $\mathrm{Lim}$ 등(2011)의 방법 에 따라 추출되었다. 막자사발에 고구마 $(5 \mathrm{~g})$ 와 $10 \mathrm{mM}$ phosphate buffer (pH 7.4) $15 \mathrm{~mL}$ 를 넣고 마쇄하여 8겹의 나일론 거즈를 통해 여과하였다. 여과액을 $4^{\circ} \mathrm{C}$ 에서 $8,000 \times \mathrm{g}$ 의 원심속도로 20 분간 원심분리 하고, 상징액을 모아 $22,000 \times \mathrm{g}$ 의 원심속도로 다 시 원심분리 $\left(4^{\circ} \mathrm{C}, 20 \mathrm{~min}\right)$ 한 후 침전물을 $10 \mathrm{mM}$ phosphate buffer (pH 7.4) $2 \mathrm{~mL}$ 로 부유하였다. 부유액의 단백질 함량은 Bradford (1976)법으로 측정하였고, 효소 조추출물의 $\alpha$-amylase, peroxidase 및 IAA oxidase 활성은 각각 660,470 및 $530 \mathrm{~nm}$ 에서 분광광도법(Optizen 2120AU, Mecasys)으로 측정하였다. 통계분석. 모든 시험에서 얻어진 성적은 SPSS $12.0 \mathrm{~K}$ (SPSS Inc., USA)를 이용하여 전자빔 조사구와 대조구간 유의차 검정 을 신뢰도 $95 \%$ 수준에서 Dunnett 검정으로 실시하였다.

\section{결과 및 고찰}

고구마 발아에 끼치는 전자빔의 효과. 전자빔 조사 후 $4^{\circ} \mathrm{C}$ 에 저장된 대조구와 전자빔 조사구 $(0.1-1.0 \mathrm{kGy})$ 의 박스 내 모든 고구마 및 12 와 $25^{\circ} \mathrm{C}$ 에 저장된 고구마 중 대조구를 제외한 모 든 전자빔 조사구의 박스 상층에 위치한 고구마는 8 주 동안 발 아가 억제되었지만, 12 와 $25^{\circ} \mathrm{C}$ 에 저장된 대조구 모두와 전자빔 조사구의 중간층과 하층에 위치한 고구마는 각각 저장 후 6 주 와 4주에서 발아가 시작되었다(Table 1, Fig 1). 고구마의 발아 정도는 저장기간의 경과, 조사선량의 감소 및 전자빔 조사시 조 사장치와 고구마 간 간격의 증가와 함께 증가하였고, 발아율은 12 와 $25^{\circ} \mathrm{C}$ 저장 후 8 주에서 각각 대조구 $11.2-12.4$ 와 $70.5-$ $74.2 \%$, 전자빔 조사구 8.6-11.3과 42.7-48.7\% 이었다(Table 1). 12 와 $25^{\circ} \mathrm{C}$ 의 저장에 있어 박스 내 상층부만의 발아억제 결과는 고구마의 발아억제에 전자빔 적용 시 시료의 높이를 $7 \mathrm{~cm}$ 이하 로 하여야 만이 효과적으로 발아를 억제할 수 있음을 나타냈다. 전자빔 조사에 의한 고구마의 식품특성 변화. 상층 고구마의 중 량은 저장기간의 경과, 저장온도의 상승과 함께 감소하였다. 4, 12 , 및 $25^{\circ} \mathrm{C}$ 저장 후 8 주에서 대조구와 $1.0 \mathrm{kGy}$ 전자빔 조사구 의 고구마 중량은 각각 8.9 와 $8.7,13.4$ 와 13.1 및 23.3 과 $22.5 \%$ 가 감소하였으나 조사구간 현저한 차이를 나타내지 않았 고(Fig. 2), 0.1-0.5 kGy 전자빔 조사구 고구마 또한 대조구와 
Table 1 Sprouting rate of sweet potato roots with different storage temperature and storage period

\begin{tabular}{|c|c|c|c|c|c|c|c|}
\hline \multirow{3}{*}{$\begin{array}{l}\text { Stroage temp. } \\
\qquad\left({ }^{\circ} \mathrm{C}\right)\end{array}$} & \multirow{3}{*}{$\begin{array}{l}\text { Storageperiod } \\
\quad \text { (weeks) }\end{array}$} & \multirow{3}{*}{ Layer } & \multicolumn{5}{|c|}{ Sprouting rate $(\%)$} \\
\hline & & & \multicolumn{5}{|c|}{ Irradiationdose (kGy) } \\
\hline & & & 0 & 0.1 & 0.2 & 0.5 & 1 \\
\hline \multirow{5}{*}{4} & 0 & Total & 0 & 0 & 0 & 0 & 0 \\
\hline & 2 & Total & 0 & 0 & 0 & 0 & 0 \\
\hline & 4 & Total & 0 & 0 & 0 & 0 & 0 \\
\hline & 6 & Total & 0 & 0 & 0 & 0 & 0 \\
\hline & 8 & Total & 0 & 0 & 0 & 0 & 0 \\
\hline \multirow{11}{*}{12} & 0 & Total & 0 & 0 & 0 & 0 & 0 \\
\hline & 2 & Total & 0 & 0 & 0 & 0 & 0 \\
\hline & 4 & Total & 0 & 0 & 0 & 0 & 0 \\
\hline & \multirow{4}{*}{6} & Upper & $6.8 \pm 1.4$ & 0 & 0 & 0 & 0 \\
\hline & & Middle & $7.4 \pm 2.2$ & $6.2 \pm 1.1$ & $6.4 \pm 1.5$ & $5.3 \pm 1.8$ & $4.9 \pm 0.8$ \\
\hline & & Below & $7.2 \pm 1.2$ & $6.7 \pm 1.2$ & $5.7 \pm 1.2$ & $7.2 \pm 1.5$ & $5.3 \pm 1.4$ \\
\hline & & Total & $7.1 \pm 2.4$ & $2.4 \pm 0.4$ & $2.2 \pm 1.4$ & $3.1 \pm 1.2$ & $2.2 \pm 1.2$ \\
\hline & \multirow{4}{*}{8} & Upper & $12.4 \pm 1.5$ & 0 & 0 & 0 & 0 \\
\hline & & Middle & $11.6 \pm 1.2$ & $8.9 \pm 1.6$ & $9.4 \pm 1.7$ & $8.6 \pm 2.7$ & $9.2 \pm 2.3$ \\
\hline & & Below & $11.2 \pm 1.4$ & $11.3 \pm 2.2$ & $10.9 \pm 1.4$ & $9.5 \pm 3.2$ & $8.9 \pm 2.6$ \\
\hline & & Total & $11.7 \pm 2.3$ & $4.2 \pm 0.9$ & $5.8 \pm 1.2$ & $5.3 \pm 0.9$ & $4.6 \pm 2.1$ \\
\hline \multirow{14}{*}{25} & 0 & Total & 0 & 0 & 0 & 0 & 0 \\
\hline & 2 & Total & 0 & 0 & 0 & 0 & 0 \\
\hline & \multirow{4}{*}{4} & Upper & $16.4 \pm 2.0$ & 0 & 0 & 0 & 0 \\
\hline & & Middle & $15.6 \pm 2.4$ & $9.8 \pm 2.7$ & $10.2 \pm 2.4$ & $7.3 \pm 2.4$ & $6.8 \pm 2.6$ \\
\hline & & Below & $17.6 \pm 2.0$ & $9.6 \pm 1.8$ & $10.5 \pm 2.4$ & $8.6 \pm 1.2$ & $7.6 \pm 0.9$ \\
\hline & & Total & $16.5 \pm 1.2$ & $4.4 \pm 2.3$ & $5.7 \pm 1.0$ & $4.1 \pm 1.4$ & $3.2 \pm 1.6$ \\
\hline & \multirow{4}{*}{6} & Upper & $50.4 \pm 2.8$ & 0 & 0 & 0 & 0 \\
\hline & & Middle & $52.4 \pm 2.2$ & $39.5 \pm 3.7$ & $36.4 \pm 3.7$ & $35.5 \pm 3.3$ & $34.2 \pm 3.2$ \\
\hline & & Below & $51.6 \pm 4.2$ & $41.5 \pm 3.3$ & $34.2 \pm 2.8$ & $37.2 \pm 3.2$ & $34.5 \pm 3.2$ \\
\hline & & Total & $51.4 \pm 3.2$ & $24.2 \pm 2.4$ & $22.6 \pm 3.1$ & $20.5 \pm 2.4$ & $24.6 \pm 3.6$ \\
\hline & \multirow{4}{*}{8} & Upper & $72.2 \pm 2.3$ & 0 & 0 & 0 & 0 \\
\hline & & Middle & $70.5 \pm 3.2$ & $45.6 \pm 2.5$ & $45.9 \pm 4.2$ & $44.2 \pm 4.1$ & $42.7 \pm 3.8$ \\
\hline & & Below & $74.2 \pm 2.8$ & $48.7 \pm 2.5$ & $46.2 \pm 4.6$ & $44.4 \pm 2.8$ & $45.2 \pm 2.5$ \\
\hline & & Total & $71.6 \pm 3.4$ & $34.4 \pm 4.2$ & $32.1 \pm 4.6$ & $30.4 \pm 3.4$ & $31.2 \pm 2.8$ \\
\hline
\end{tabular}

Fig. 1 Sweet potato stored for 6 weeks at $25^{\circ} \mathrm{C}$ after electron beam irradiation.

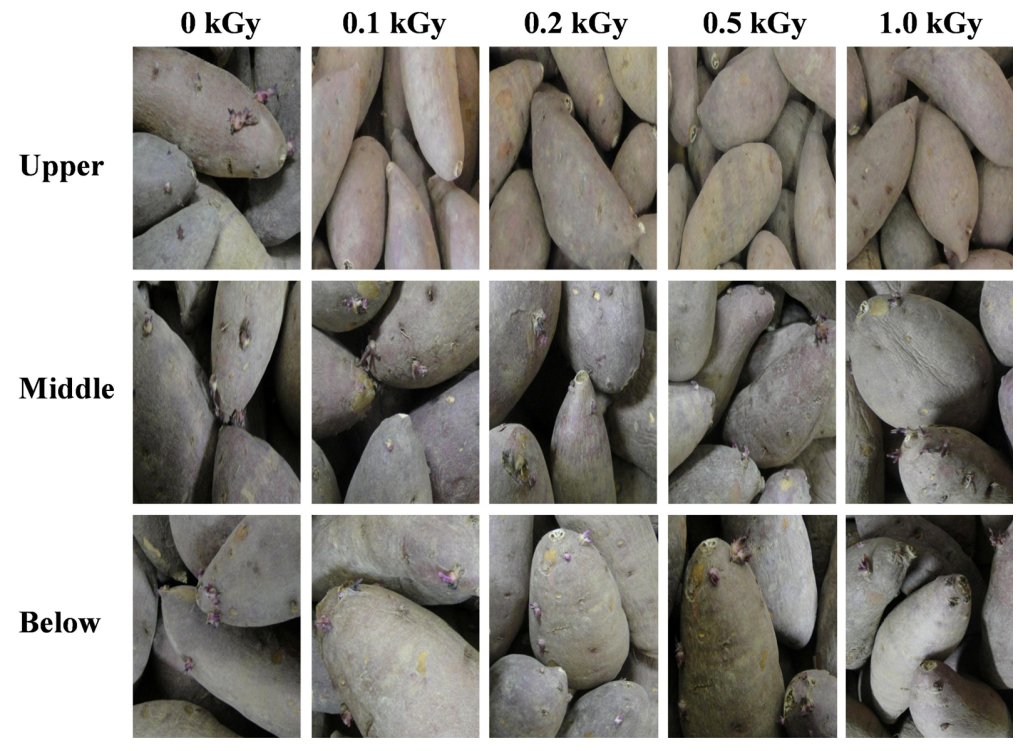


Table 2 Changes of hardness, $\mathrm{pH}$, and sugar content of upper positioned sweet potato after electron beam irradiation with different storage temperature and storage period

\begin{tabular}{|c|c|c|c|c|c|c|c|}
\hline \multirow{2}{*}{$\begin{array}{l}\text { Storage temp. } \\
\qquad\left({ }^{\circ} \mathrm{C}\right)\end{array}$} & \multirow{2}{*}{$\begin{array}{l}\text { Storage period } \\
\text { (weeks) }\end{array}$} & \multicolumn{2}{|c|}{ Hardness $\left(\mathrm{g} \mathrm{cm}^{-2}\right)$} & \multicolumn{2}{|c|}{$\mathrm{pH}$} & \multicolumn{2}{|c|}{ Sugar content (Brix) } \\
\hline & & $0 \mathrm{kGy}$ & $1.0 \mathrm{kGy}$ & $0 \mathrm{kGy}$ & $1.0 \mathrm{kGy}$ & $0 \mathrm{kGy}$ & $1.0 \mathrm{kGy}$ \\
\hline \multirow{5}{*}{4} & 0 & $3912 \pm 284$ & $3816 \pm 212$ & $6.1 \pm 0.1$ & $6.1 \pm 0.2$ & $14.4 \pm 1.2$ & $14.4 \pm 1.6$ \\
\hline & 2 & $3936 \pm 172$ & $3852 \pm 246$ & $6.1 \pm 0.2$ & $6.2 \pm 0.2$ & $15.0 \pm 1.4$ & $14.6 \pm 1.0$ \\
\hline & 4 & $4057 \pm 240$ & $3914 \pm 224$ & $6.2 \pm 0.2$ & $6.1 \pm 0.2$ & $16.1 \pm 1.2$ & $14.4 \pm 1.3$ \\
\hline & 6 & $4214 \pm 167$ & $4124 \pm 232$ & $6.3 \pm 0.2$ & $6.3 \pm 0.1$ & $16.5 \pm 1.6$ & $14.2 \pm 1.7$ \\
\hline & 8 & $4237 \pm 247$ & $4154 \pm 253$ & $6.4 \pm 0.1$ & $6.2 \pm 0.2$ & $16.6 \pm 1.4$ & $14.4 \pm 1.6$ \\
\hline \multirow{5}{*}{12} & 0 & $3942 \pm 206$ & $3882 \pm 186$ & $6.1 \pm 0.1$ & $6.2 \pm 0.1$ & $14.4 \pm 1.7$ & $14.5 \pm 1.4$ \\
\hline & 2 & $4062 \pm 154$ & $3922 \pm 272$ & $6.2 \pm 0.1$ & $6.0 \pm 0.2$ & $14.4 \pm 1.6$ & $14.9 \pm 1.6$ \\
\hline & 4 & $4102 \pm 252$ & $4057 \pm 135$ & $6.1 \pm 0.1$ & $5.9 \pm 0.2$ & $14.9 \pm 1.9$ & $15.8 \pm 1.7$ \\
\hline & 6 & $4236 \pm 274$ & $4130 \pm 174$ & $6.2 \pm 0.2$ & $6.1 \pm 0.2$ & $15.8 \pm 1.6$ & $16.3 \pm 1.8$ \\
\hline & 8 & $4250 \pm 195$ & $4110 \pm 324$ & $6.3 \pm 0.2$ & $6.1 \pm 0.1$ & $16.4 \pm 1.8$ & $16.4 \pm 2.2$ \\
\hline \multirow{5}{*}{25} & 0 & $4012 \pm 186$ & $3985 \pm 256$ & $6.1 \pm 0.2$ & $6.1 \pm 0.1$ & $14.4 \pm 1.6$ & $14.2 \pm 1.4$ \\
\hline & 2 & $4183 \pm 274$ & $4030 \pm 164$ & $6.1 \pm 0.3$ & $5.9 \pm 0.2$ & $14.6 \pm 1.4$ & $14.4 \pm 2.0$ \\
\hline & 4 & $4265 \pm 230$ & $4186 \pm 182$ & $6.2 \pm 0.1$ & $6.0 \pm 0.3$ & $15.2 \pm 1.8$ & $15.8 \pm 1.8$ \\
\hline & 6 & $4245 \pm 184$ & $4130 \pm 198$ & $6.1 \pm 0.2$ & $6.1 \pm 0.1$ & $15.8 \pm 2.1$ & $16.2 \pm 2.3$ \\
\hline & 8 & $4252 \pm 314$ & $4135 \pm 230$ & $6.0 \pm 0.1$ & $5.9 \pm 0.3$ & $16.0 \pm 1.6$ & $16.1 \pm 1.8$ \\
\hline
\end{tabular}

현저한 차이를 나태내지 않았다(결과 미제시).

대조구와 전자빔 조사구 중 모든 저장온도와 저장기간에서 가장 큰 변화를 나타낸 $1.0 \mathrm{kGy}$ 에 대한 경도, $\mathrm{pH}$ 및 당도 변 화를 Table 2에 나타냈다. 대조구와 전자빔 조사구 모두 저장 기간의 경과와 저장온도의 상승과 함께 다소 경도가 증가하였 고, 전자빔 조사구가 대조구보다 다소 낮은 값을 나타냈으나 두 처리구간 현저한 차이는 없었다. 대조구와 전자빔 조사구의 $\mathrm{pH}$ 는 저장기간과 저장온도에 따른 큰 변화 없이 일반 고구마의 $\mathrm{pH}$ 에 해당하는 5.9-6.4의 값을 나타내 전자빔은 고구마의 $\mathrm{pH}$ 에 영향을 끼치지 않는 것으로 판단되었다. 당도는 모든 저장 온도에서 저장기간의 경과와 함께 다소 증가하였으나 대조구와 현저한 차이를 나타내지 않았다. 또한 $0.1-0.5 \mathrm{kGy}$ 전자빔 조사 구도 모든 저장온도와 저장기간에서 경도, $\mathrm{pH}$ 및 당도에 있어 서 대조구와 현저한 차이를 나타내지 않았다(결과 미제시).

전자빔에 의한 고구마의 대표적인 기능성 물질인 $\beta$-carotene 과 vitamin $\mathrm{C}$ 함량변화를 Fig. 3에 나타냈다. 전자빔 조사 후 $25^{\circ} \mathrm{C}$ 에 저장한 상층 고구마의 $\beta$-carotene 함량은 저장기간의 경 과와 함께 다소 증가하였으나 대조구와 현저한 차이를 나타내 지 않았고, vitamin $\mathrm{C}$ 함량도 저장기간 동안 큰 변화 없이 대 조구와 유사한 값을 나타냈다. 또한 4 와 $12^{\circ} \mathrm{C}$ 에 저장된 고구마 와 $25^{\circ} \mathrm{C}$ 에 저장된 중간층과 하층의 고구마도 또한 유사한 결과 를 나타냈다(결과 미제시). 이는 $1 \mathrm{kGy}$ 미만의 전자빔 조사에서 포도의 $\beta$-carotene과 vitamin $\mathrm{C}$ 함량이 크게 변화하지 않은 Girennavar 등(2008)의 결과와 유사하였다.

발아관련 효소의 활성에 끼치는 전자빔의 효과. 고구마의 발아 는 $25^{\circ} \mathrm{C}$ 의 저장에서 가장 높게 나타나(Table 1) Fig. 4에는 $25^{\circ} \mathrm{C}$ 저장 박스의 상층 고구마에 대한 결과만을 나타냈다. 발아 중 현저히 합성되는 $\alpha$-amylase는 배유의 amylose와 amylopectin 과 같은 전분의 $\alpha-1,4$-glucan 결합을 무작위로 가수분해하여 단 당류를 생성함으로써 식물 성장을 돕는 것으로 알려져 있다 (Helland 등, 2002). 대조구의 $\alpha$-amylase의 활성은 저장 후 2주 부터 다소 증가하여 발아개시점(저장 후 4주)에서 가장 높은 활 성을 나타낸 후 다소 감소하였다. 한편, 발아가 완전히 억제된

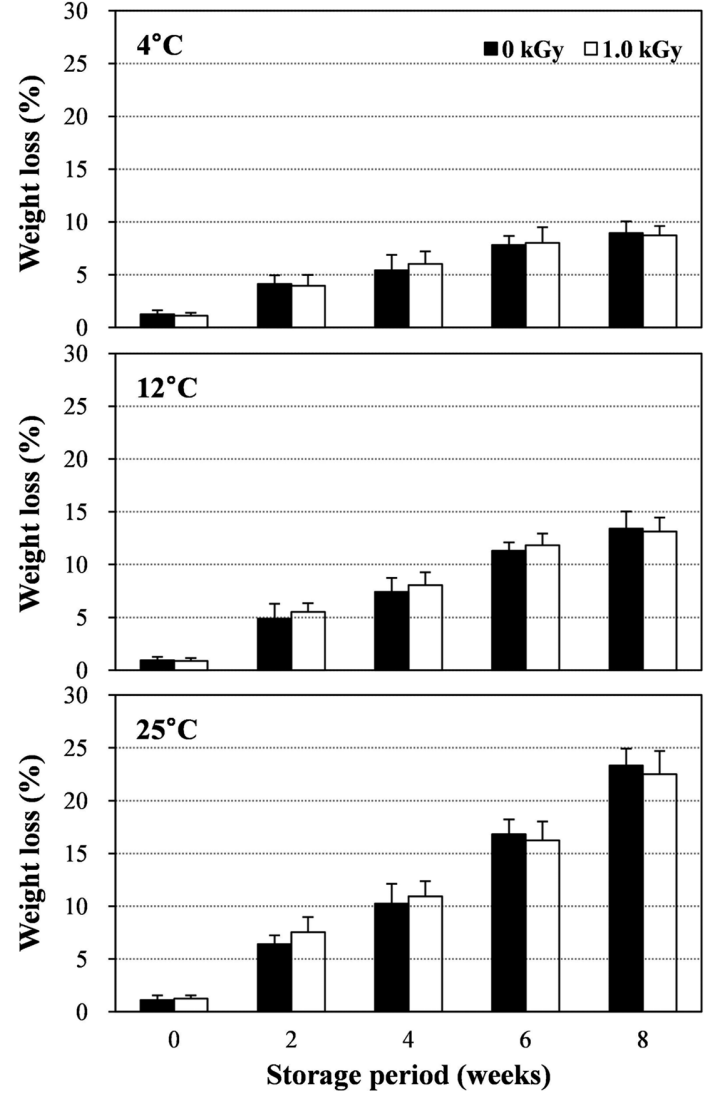

Fig. 2 Weight loss of upper positioned sweet potato with/without electron beam irradiation with different storage temperature and storage period. Vertical bars represent $\pm \mathrm{SE}$ of the means.

전자빔 조사 상층 고구마의 $\alpha$-amylase 활성은 대조구와 유사한 정도의 활성을 나타냈다. 따라서 전자빔에 의한 $\alpha$-amylase의 활 

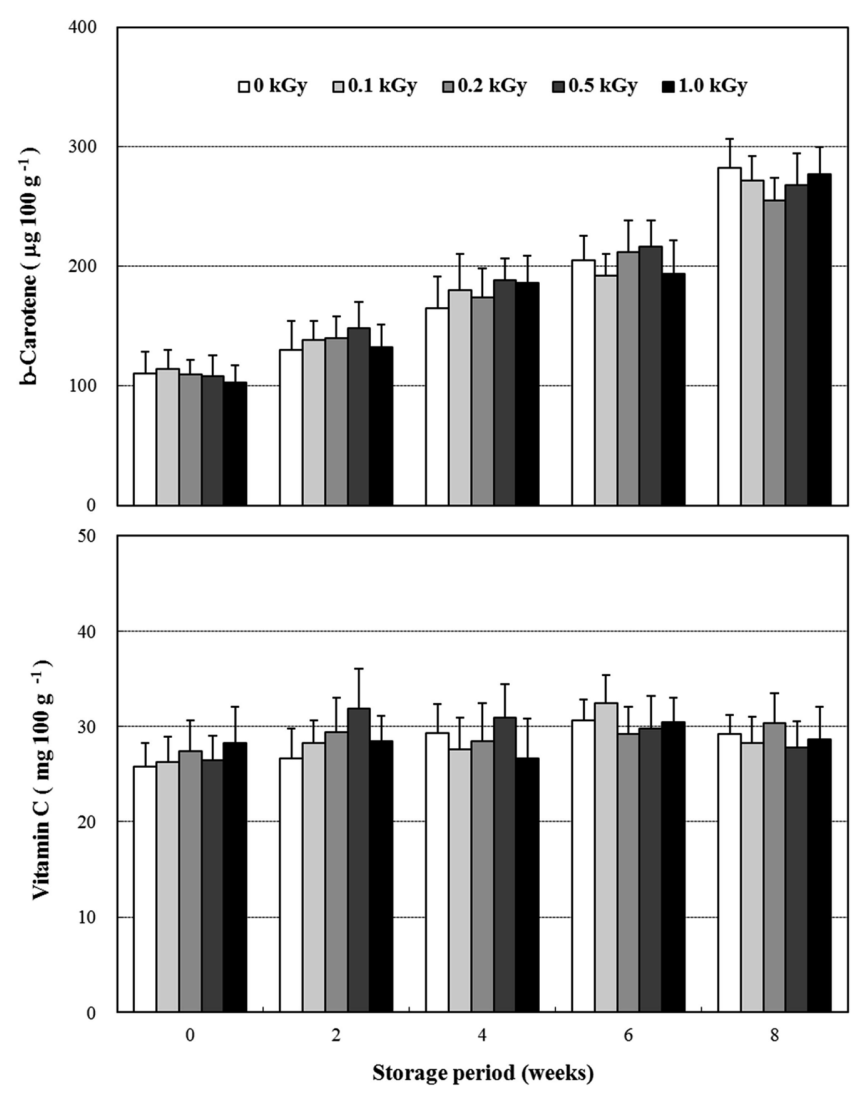

Fig. $3 \beta$-Carotene and vitamin $\mathrm{C}$ content of upper positioned sweet potato with/without electron beam irradiation with different storage temperature and storage period. Vertical bars represent $\pm \mathrm{SE}$ of the means.

성변화는 고구마의 발아억제와 직접적인 관련은 없는 것으로 판 단된다.

Lagrimini 등(1997)의 보고에 의하면 peroxidase는 세포의 성 장과 팽창 및 옥신 분해대사에 작용하는 것으로 알려져 있다. 또한 IAA oxidase의 활성도 가지고 있어 내생 옥신의 함량조 절 가능성도 제기되었다(Gazaryan 등, 1996; Faivre-Rampant 등, 1998). 0.5와 $1 \mathrm{kGy}$ 의 전자빔이 조사된 고구마의 peroxidase 활성은 다소 감소하지만 저장 후 6주까지 활성을 유지한 것에 반해 대조구와 0.1 과 $0.2 \mathrm{kGy}$ 의 전자빔이 조사된 시료에서는 급 격히 활성이 감소하였다. 또한 전자빔이 조사된 고구마의 peroxidase 활성은 저장 후 4주부터 대조구보다 크게 나타났다. 이는 전자빔 조사에 의해 생성된 radical의 작용으로 perxoidase 가 활성화 된 것으로 판단되고, 감마선 조사에 의한 감자의 IAA peroxidase 활성 증가와 유사한 결과를 나타냈다(Ussuf 와 Nair, 1974). 따라서 전자빔 조사에 의해 활성이 증가한 peroxidase는 IAA의 함량 감소를 유도함으로써 고구마의 발아 억제에 부분적으로 기여하는 것으로 판단된다.

$\mathrm{IAA}$ 는 발아에 있어서 중요한 역할을 하는 천연식물 호르몬 으로(Slavov 등, 2004) IAA oxidase에 의해 양이 조절되어 식 물성장에 관여함을 보고하였다(Park 등, 1983). 대조구의 IAA oxidase의 활성은 저장기간의 경과와 함께 감소한 것에 반해 전 자빔이 조사된 상층부의 고구마는 발아개시점부터 증가해 대조 구보다 높은 활성을 나타냈다. 이는 전자빔 조사에 의해 생성 된 radical에 의해 IAA oxidase가 활성화 된 것으로 판단되고,
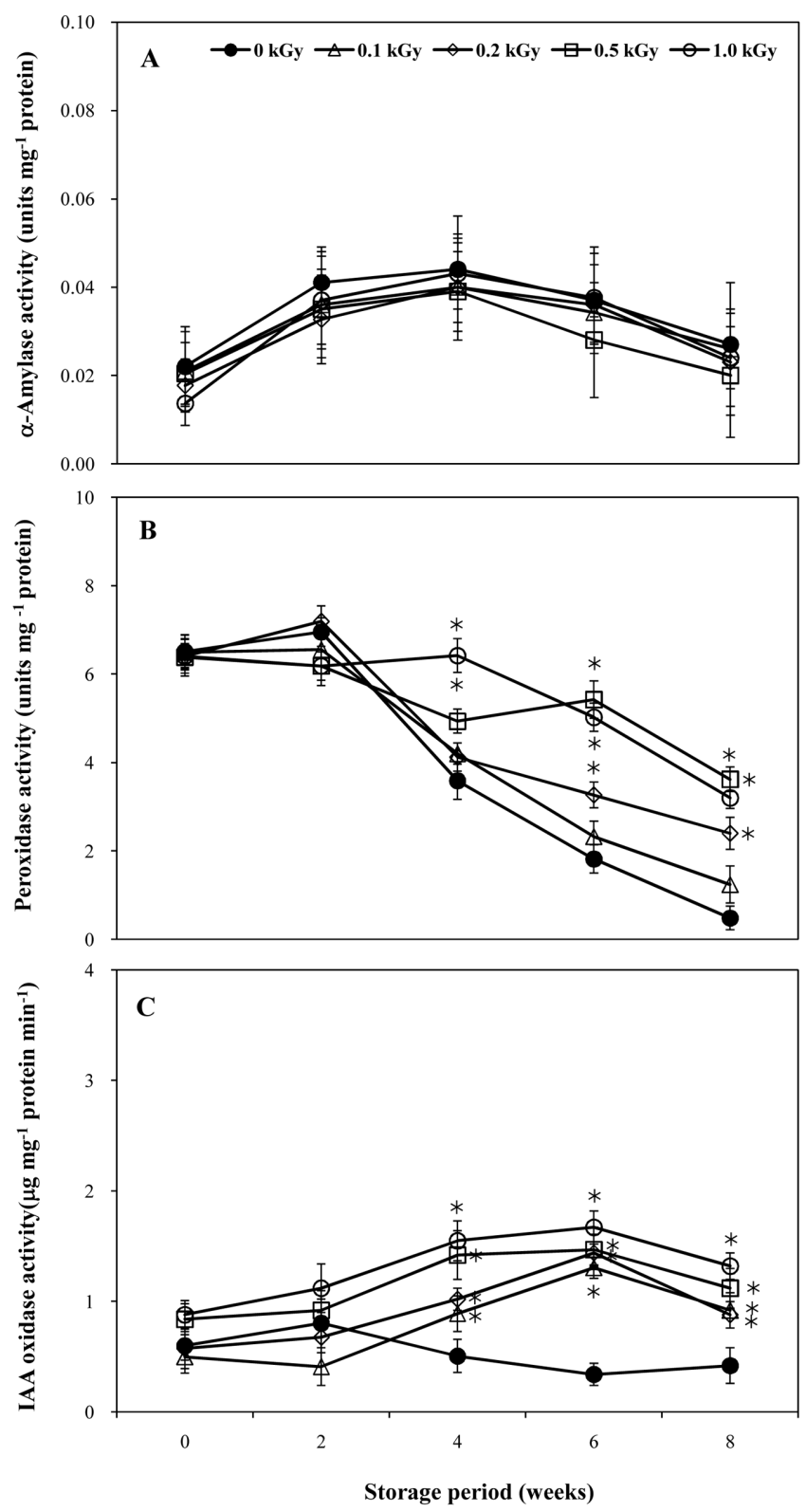

Fig. $4 \alpha$-Amylase, peroxidase, and IAA oxidase activity of sweet potato with/without electron beam irradiation with different storage period at $25^{\circ} \mathrm{C}$. Vertical bars represent $\pm \mathrm{SE}$ of the means. *Significantly different from control $(p<0.05)$.

옥수수 자엽의 IAA oxidase 활성이 감마선 조사에 의해 증가 하는 것과 유사하였다(Momiyama 등, 1999). 따라서 전자빔이 조사된 상층 고구마의 IAA oxidase 증가는 내생 IAA 수준을 감소시켜 직접적으로 고구마의 발아를 억제하는 것으로 판단된 다. 또한, $4^{\circ} \mathrm{C}$ 에 저장된 고구마는 모든 저장기간 동안 발아가 억제되었으며 $\alpha$-amylase, peroxidase 및 IAA oxidase의 활성은 대조구와 전자빔 조사구간 현저한 차이를 나타내지 않았다. $12^{\circ} \mathrm{C}$ 저장의 경우도 $25^{\circ} \mathrm{C}$ 저장의 경우와 유사한 결과를 보였으나 peroxidase와 IAA oxidase는 $25^{\circ} \mathrm{C}$ 저장보다 낮은 활성을 나타 냈다(결과 미제시). 


\section{초 록}

고구마의 식품특성에 변화 없이 발아를 억제할 수 있는 물리적 처리법으로 전자빔의 적용가능성을 조사하였다. 전자빔 조사 후 12 와 $25^{\circ} \mathrm{C}$ 에 저장된 모든 대조구와 전자빔이 조사된 중간층 $(7-$ $12 \mathrm{~cm})$ 과 하층 $(12-17 \mathrm{~cm})$ 에 위치하는 고구마는 저장 후 6 주와 4 주에 각각 발아가 시작되었다. 12 와 $25^{\circ} \mathrm{C}$ 에 저장된 고구마의 발아율은 저장기간의 경과, 조사선량의 감소, 전자빔과 고구마 간 간격의 증가와 함께 증가하였고 발아율은 12 와 $25^{\circ} \mathrm{C}$ 저장 후 8주에서 각각 대조구 $11.2-12.4$ 와 $70.5-74.2 \%$, 전자빔 조사 구 8.6-11.3과 $42.7-48.7 \%$ 이었다. 한편, $4^{\circ} \mathrm{C}$ 에 저장된 모든 고구마와 전자빔 조사 후 12 와 $25^{\circ} \mathrm{C}$ 에 저장된 상층 $(0-7 \mathrm{~cm})$ 에 위치한 고구마의 발아는 peroxidase와 indole acetic acid (IAA) oxidase의 활성증가로 인해 완전히 억제되었다. 또한 전자빔이 조사된 모든 시료는 경도, $\mathrm{pH}$, 당도, 중량감소, vitamin $\mathrm{C}$ 함량 및 $\beta$-carotene 함량에 있어서 대조구와 현저한 차이가 없었다. 따라서 고구마를 박스에 포장하기 전 $0.1 \mathrm{kGy}$ 이상의 전자빔 조사 시 $25^{\circ} \mathrm{C}$ 에 저장하여도 식품특성에 변화 없이 발아를 효과 적으로 억제할 수 있을 것으로 판단된다.

Keywords 고구마 · 발아저해 · 전자빔 · $\alpha$-amylase · indole acetic acid oxidase $\cdot$ peroxidase

Acknowledgment This research was supported by the Research Program through the Animal, Plant and Fisheries Quarantine and Inspection Agency (1103-000070).

\section{참고문헌}

AFMC (2010) Import and Export News of Agricultural and Marine products. Agricultural and Fishery Marketing Corporation, Seoul, Korea.

Ameny MA and Wilson PW (1997) Relationship between hunter color value and $\beta$-carotene contents in white flashed African sweetpotatoes (IpomoeabatatasL.). J Food Compos Anal 1, 341-52.

Bradford MM (1976) A rapid and sensitive method for the quantitation of microgram quantities of protein utilizing the principle of protein-dye binding. Anal Biochem 72, 248-54.

Chung BY, Kim JS, Lee MH, Lee KS, Hwang SA, and Cho JY (2009) Degradation of ampicillin in pig manure slurry and an aqueous ampicillin solution using electron beam irradiation. Radiat Phys Chem 78, 711-3.

Dias MG, Oliveira L, Camoes MF, Nunes B, Versloot P, and Hulshof PJ (2010) Critical assessment of three high performance liquid chromatography analytical methods for food carotenoid quantification. $J$ Chromatogra A 1217, 3494-502.

EFSA (2011) Statement of EFSA, European Food Safety Authority, Parma, Italy.

Faivre-Rampant O, Kevers C, Bellini C, and Gaspar T (1998) Peroxidase activity, ethylene production, lignifications and growth limitation in shoots of a non-rooting mutant of tobacco. Plant Physiol Biochem 36, 873-7.

FDA (1986) Irradiation in the production, processing and handling of food Federal Register, Apr, 18, 51 FR 13376, USA.

Gazaryan IG, Lagrimini LM, Ashby AG, and Thorneley NF (1996) Mechanism of indole-3-acetic acid oxidation by plant peroxidases: anaerobic stopped-flow spectrophotometric studies on horseradish and tobacco peroxidases. Biochem J 313, 841-7.

Girennavar B, Jayaprakasha GK, Mclin SE, Maxin J, Yoo KS, and Patil BS
(2008) Influence of electron-beam irradiation on bioactive compounds in grapefruits (Citrus paradise Macf.). J Agric Food Chem 56, 10941-6.

Helland MH, Wicklund T, and Narvhus JA (2002) Effect of germination time on alpha-amylase production and viscosity of maize porridge. Food Res Int 35, 315-21.

Kagan J, Hasson M, and Grynspan F (1984) The inactivation of acetylcholinesterase by alpha-terthienyl and ultraviolet light studies in vitro and in larvae of the mosquito. Biochim Biophys Acta 802, 442-7.

KFDA (2004) Korean Food Code. pp. 837-40, Korea Food and Drug Administration, Seoul, Korea.

KFDA (2009) Korea Food Standard Code, Korea Food and Drug Administration, Seoul, Korea.

Kirca A, Ozkan M, and Cemeroglu B (2007) Effects of temperature, solid content and $\mathrm{pH}$ on the stability of black carrot anthocyanins. Food Chem 101, 212-8.

Kirnski NI (1993) Actions of carotenoids in biological systems. Annual Rev Nutr 13, 561-87.

Kottapalli B, Wolf-Hall CE, and Schwarez P (2006) Effect of electron-beam irradiation on the safety and quality of Fusarium-infected malting barley. Int J Food Microbiol 110, 224-31.

Lagrimini LM, Joly RJ, Dunlap JR, and Liu TTY (1997) Characterization of antisense transformed plants deficient in the tobacco anionic peroxidase. Plant Mol Biol 33, 887-95.

Latorre ME, Narvaiz P, Rojas AM, and Cerschenson LN (2010) Effects of gamma irradiation on bio-chemical and physic-chemical parameters of fresh-cut red beet (Beta vulgaris L. var. conditiva)root. J Food Eng 98, $178-91$.

MLHW (2006) Report of Food Radiation, Japan Atomic Energy Commision, Ministry of Health, Labor and Welfare, Tokyo, Japan.

Momiyama M, Koshiba T, Furukawa K, Kamiya Y, and Sato M (1999) Effects of $\gamma$-irradiation on elongation and indole-3-acetic acid level of maize (Zea mays) coleoptiles. Environ Exp Bot 41, 131-43.

Park RD, Suh YT, and Shin YK (1983) Changes in the activity of IAA oxidase during chilling pea seedlings (in Korean). J Korean Agric Chem Soc 26, 132-6.

Reddy NN and Sistrunk WA (1980) Effect of cultivar, size, storage, and cooking method on carbohydrates and some nutrients of sweetpotatoes. $J$ Food Sci 45, 682-4.

Saha A, Mandal PC, and Bhattacharyya SN (1995) Radiation-induced inactivation of enzymes-A review. Radiat Phys Chem 46, 123-45.

Shi Z, Bassa IA, Gabriel SL, and Francis FJ (1992) Anthocyanin pigments of sweet potatoes-Ipomoea batatas. J Food Sci 57, 755-70.

Sitton JW, Borsa J, Schultz TR, and Maguire JD (1995) Electron beam irradiation effects on wheat quality, seed vigor, and viability and pathogenicity of teliospores of Tilletia controversa and T. tritici. Plant Dis 79, 586-9.

Slavov S, Van Onckelen H, Batchvarova R, Atanassov A, and Prinsen E (2004) IAA production during germination of Orobanche spp. Seeds $J$ Plant Physiol 161, 847-53.

Suda Y, Nakabayashi J, Matsuo I, and Aizawa S (1999) Functional equivalency between Otx2 and Otx1 in development of the rostral head. Development 126, 743-57.

USDA-APHIS (2011) Fruit and vegetables import requirements (FAVIR). United States Department of Agriculture, Animal and plant Health Inspection Service, Washington, USA.

Ussuf KK and Nair M (1974) Effect of $\gamma$-irradiation on indole acetic acid synthesizing system and its significance in sprout inhibition of potatoes. Radiat Bot 14, 251-6.

Yun HJ, Joe MH, Kwon JH, Lim BL, and Kim DH (2008) Quality characteristics of grapes during post-irradiation storage at different temperatures (in Korean). Korean J Food Preserv 15, 648-55.

Zacev AN, Shillinger JI, Kamaldinova ZM, and Osipova IN (1975) Toxicologic and hygienic investigation of potatoes irradiated with a beam of fast electrons and $\gamma$-rays to control sprouting. Toxicology 4, 3416. 